\title{
Hukum dan Peningkatan Efisiensi Birokrasi
}

\author{
M. Fajrul Falaakh
}

\section{Pendahuluan}

I ndonesia sering dikategorikan sebagai bureaucratic polity, di mana peran birokrasi dalam kehidupan masyarakat begitu luas. Birokrasi tak hanya membatasi diri untuk terlibat dalam aktifitas yang dikategorikan public, melainkan terlibat pula dalam banyak aktifitas private. Hal ini bukan hanya menyangkut kehidupan ekonomi melalui berbagai badan usaha milik negara (BUMN), yang dimungkinkan berdasarkan derivasi dari ketentuan UUD 1945 Pasal 33 , melainkan juga dalam banyak aspek kehidupan politik, sosial dan budaya warganegara yang sebenarnya termasuk kategori private. Dalam kehidupan moderen yang makin kompleks, tampaknya peran birokrasi yang meluas itu tak terelakkan, apalagi di negara dengan jumlah penduduk yang banyak dan wilayah yang luas seperti indonesia.

Namun banyak komentar telah dikemukakan, bahwa birokrasi Indonesia sering menjadi beban sosial dan ekonomi bagi masyarakat karena lamban dalam menyelesaikan berbagai persoalan dan tidak efisien, bahkan seringkali bertindak tidak adil. Ditambah dengan desakan liberalisasi perdagangan, yang berpangkal dari pandangan bahwa negara dan birokrasinya harus makin mengurangi perannya dalam perekonomian, maka efisiensi birokrasi merupakan tuntutan yang dewasa ini mengemuka. Dengan kata lain, bagaimana hendak mewujudkan ideal type birokrasi yang dikatakan Weber, bahwa "... the purely bureaucratic type of administrative organization ... is ... capable of attaining the highest degree of efficiency".

Karena itu salah satu agenda besar yang dihadapi dalam membicarakan birokrasi Indonesia adalah mengefisienkan kinerja birokrasi. Hal ini diharapkan dapat terpenuhi melalui reformasi kelembagaan, seperti perampingan struktur birokrasi, dan peningkatan pelayanan birokrasi. Pertanyaan utama yang akan dijawab dalam tulisan ini adalah, pertama, sejauh mana mekanisme hukum berpotensi untuk mendukung efisiensi itu dan bagaimana hukum dapat ikut mengefisienkan kinerja birokrasi. Kedua, jika mekanisme hukum kurang berpotensi untuk itu, agenda reformasi apakah yang tampaknya mendesak untuk dilakukan?

Kedua pertanyaan tersebut menyangkut struktur dan perilaku birokrasi, namun 
perspektif ketatanegaraan cenderung memusatkan perhatian pada aspek struktural institusional birokrasi. Aspek terakhir ini hanya merupakan salah satu ciri khas birokrasi yang telah dikemukakan Weber, yakni bahwa birokrasi diatur berdasarkan “... a consistent system of abstract rules ...(and) consist of the application of these rules to particular case". Dengan kata lain, sisi hukum merupakan standar umum dari aktifitas birokrasi.

Namun persis pada standar umum inilah sering terjadi distorsi. Pertama, praktik ketatanegaraan Indonesia belum menetapkan standar umum birokrasi yang merupakan produk hukum demokratik. Standar yang ada justru lebih didasarkan pada praktik dan kepentingan birokrasi sendiri. Kedua, terhadap standar dan perilaku birokrasi belum terdapat pengawasan yang memadai. Pengawasan ini dapat dilakukan oleh lembaga perwakilan rakyat, langsung oleh rakyat melalui lembaga peradilan, atau pengawasan internal. Ketiga, pengawasan oleh hukum hanyalah terjadi secara negatifrepresif, yaitu ketika kesalahan administratif (maladministration) telah terjadi. Dalam konteks ketiga distorsi di muka, kedua pertanyaan utama yang diajukan dalam tulisan ini akan dibicarakan menurut perspektif ketatanegaraan.

Untuk pijakan diskusi, tulisan ini memahami birokrasi berdasarkan sintesis antara perspektif ekonomi-politik (politicaleconomy), administrasi negara (public administration) maupun perbandingan pemerintahan (comparative government). Dengan kata lain tulisan ini tidak memandang birokrasi sebagai 'sistem organisasi' seperti digunakan dalam perspektif sosiologis.

Perspektif ekonomi-politik membedakan birokrasi dari non-birokrasi karena birokrasi menggantungkan sumber anggaran di luar dirinya, sedangkan wilayah kerjanya bukan dalam bidang perekono- mian atau non-market (Beetham 1987: 155). Berdasarkan perspektif ini, BUMN tidak dapat dimasukkan begitu saja ke dalam birokrasi tanpa mempertimbangkan wilayah kerjanya di bidang ekonomi.

Perspektif administrasi negara memandang birokrasi berdasarkan wilayah dan sifat kerjanya yang termasuk kategori public. Karena itu BUMN, yang juga bergerak dalam bidang perekonomian yang bersifat private, tidak termasuk dalam kajian tulisan ini. Sedangkan perspektif perbandingan pemerintahan memungkinkan untuk melihat birokrasi sebagai (bagian dari) suatu tipe pemerintahan atau sistem politik.

Pijakan lain yang digunakan pula dalam tulisan ini adalah makna efisiensi birokrasi. Dalam wacana sementara ahli pembangunan, terutama dari kalangan ekonomi, efisiensi birokrasi sering diukur darikemampuannya untuk meningkatkan pertumbuhan ekonomi, sekurang-kurangnya dapat memperkecil kebocoran anggaran negara. Tulisan ini menilai, bahwa makna yang sempit tersebut tidaklah cukup memadai untuk diterapkan dalam mengukur efisiensi birokrasi. Berbeda dari perspektif tersebut, tulisan ini memandang bahwa efisiensi birokrasi haruslah dilihat dari sudut pandang tujuan-tujuan umum negara yang hendak dicapai melalui aktifitas birokrasi - seperti keadilan, ketertiban dan keamanan, di samping kesejahteraan. Tujuan-tujuan yang bersifat imaterial ini memang tidak dapat dilihat dan diukur sebagaimana mengkalkulasi produk-produk yang dihasilkan dari efisiensi usaha perekonomian.

\section{Meluasnya Peran Birokrasi}

Peran luas birokrasi dalam kehidupan kenegaraan didasarkan pada asumsi, antara lain, bahwa negara membutuhkan pemerintahan yáng dijalankan oleh para ahli. Mereka inilah yang kemudian memenuhi 
jajaran birokrasi pemerintahan, menempatkan diri dalam fungsi-fungsi permanen pemerintahan (dan kalau perlu bisa diperluas), serta memandang diri sebagai para ahli untuk berbagai masalah besar yang dihadapi masyarakat. Secara historis perkembangan seperti itu terjadi karena masyarakat membutuhkan negara, sedangkan negara modern tak bisa lagi diperintah oleh seorang despot atau diktator.

Negara dan birokrasinya lantas menjadi the necessary evil dalam kehidupan bersama. Hal ini senada dengan kecurigaan Aristoteles bahwa "... men, removed from social control, must be either beasts or gods, and are more likely to be beasts" bahwa manusia yang teriepas dari kontrol sosial adalah 'binatang buas' atau dewa, dan tampaknya lebih cenderung seperti binatang buas (Cohen dan Cohen 1951: 373). Filosof abad Pertengahan Immanuel Kant juga menyatakan bahwa: "the possession of power inevitably corrypts the free judgement of reason" -tak terelakkan bahwa pemilikan kekuasaan mengkorup (menyalahgunakan) penilaian bebas yang dipunyai oleh nalar (Cohen dan Cohen, 1951: 725).

Kalaupun pandangan filosofis atas manusia itu dapat dibantah berdasarkan perspektif optimistik, tampaknya yang terbentang adalah memilih yang kurang buruk (the least evil) dari tindakan-tindakan birokrasi dan mencegah timbulnya keburukan dari peran birokrasi yang tak terhindarkan. Masalahnya adalah, bagaimana hukum dapat mengarahkan birokrasi agar tidak memburuk dan bagaimana hukum melindungi masyarakat dari tirani birokrasi.

\section{Perspektif Hukum}

Dari perspektif hukum dapat dikemukakan bahwa birokrasi cenderung overtowering dalam beberapa kemungkinan ma- nifestasi. Pertama, sebagai konsekuensi dari sistem pemerintahan presidensial, karena sejak penunjukan menteri hingga pembentukan dan perluasan organisasi departemen merupakan hak prerogatif presiden. Konsekuensinya, birokrasi yang makin berkembang akan sulit dikendalikan tanpa peningkatan pengawasan terhadap presiden. Padahal, pengawasan yang makin intensif terhadap presiden dalam konteks politik Indonesia dewasa ini dapat mengesankan peningkatan pengawasan yang bersifat personal. Di lain pihak, meningkatnya pengawasan yang langsung ditujukan kepada menteri-menteri dan jajaran birokrasi di bawahnya justru mengesankan praktik pemerintahan parlementer yang tidak dianut oleh UUD 1945.

Kedua, jika pengawasan oleh presiden dan atau melalui menteri tidak cukup efektif, terutama mengingat masalah yang ditangani birokrasi semakin kompleks dan dimitologisasikan bersifat 'teknis', maka aktifitas birokrasi dapat terjebak ke dalam private sphere, yaitu di tangan pejabatpejabatnya. Ini tercermin dalam kebiasaan bahwa pergantian menteri dan aparat birokrasi selalu diikuti dengan perubahan kebijakan. Akibatnya, kebijakan-kebijakan birokrasi sangat diwarnai oleh hubunganhubungan yang termasuk kategori private dan lientelistic, sedangkan kepentingan masyarakat luas menjadi terancam. Dengan kata lain, hal ini membawa risiko bahwa prinsip perlakuan yang sama terhadap hakhak warganegara di depan hukum dan pemerintahan (UUD 1945 Pasal 28) lantas terabaikan.

Ketiga, kemungkinan-kemungkinan di atas terbuka luas melalui praktik legislasi yang sangat diwarnai oleh delegating proviso, yaitu praktik legislasi yang memberi kewenangan berlebihan kepada pihak eksekutif untuk menentukan pengaturan lebih jauh (Fajrul Falaakh, 1994). Ketika peng- 
aturan ini menyangkut banyak hal yang bersifat substansial bagi kehidupan masyarakat luas, maka birokrasi memperoleh kewenangan diskresioner (discretionary authority) tanpa pertanggungjawaban publik (lihat juga Wilson, 1982: 57-58).

Padahal, seperti tampak dari perspektif administrasi negara, salah satu ciri birokrasi justru pada watak public. Watak birokrasi seperti itu terlihat dari kenyataan, bahwa (a) aktifitas birokrasi menyangkut semua warganegara, khususnya dalam persoalan yang ditangani oleh unit-unit tertentu birokrasi; (b) aktifitas itu dijalankan di tengah-tengah atau sepengetahuan masyarakat (in public) dan karena itu (c) dianggap untuk kepentingan masyarakat luas (for public) (Beetham, 1987: 33-34).

Maka wajarlah jika aktifitas birokrasi harus dapat diperiksa oleh masyarakat dan dipertanggungjawabkan kepada warganegara. Jika tidak, maka birokrasi hanya akan melayani kepentingan pejabat-pejabat melalui aktifitas yang secara formal mengatasnamakan kepentingan orang banyak. Contoh-contoh untuk ini dapat dilihat pada tata-niaga berbagai komoditas yang menguntungkan, intervensi kepentingan swasta ke dalam "cabang-cabang produksi yang menguasai hajat hidup rakyat banyak" melalui kebijakan yang tak terkontrol -misalnya menyangkut terigu, listrik, otomotif, dan lain-lain.

\section{Mekanisme Hukum}

Persoalannya adalah, bagaimana menghindari peran birokrasi yang berlebihan dan tak terkendali itu agar kinerjanya dapat ditingkatkan, dalam arti bahwa birokrasi tidak bersalah-guna (corrupt) dan makin efisien. Di sini diajukan tiga jalan atau mekanisme hukum, yaitu legislative review (pengawasan oleh DPR), anticipatory juditicial review (hak uji antisipatif oleh
Mahkamah Agung), maupun administrative trial (peradilan tata-usaha negara, peratun). Melalui legislative review diharapkan agar lembaga-lembaga perwakilan rakyat meningkatkan peran untuk melakukan pengawasan terhadap pihak eksekutif, yaitu dengan mengakses aktifitas birokrasi. Judicial rewiew merupakan upaya tak langsung untuk meningkatkan efisiensi birokrasi melalui keterlibatan lembaga peradilan, khususnya Mahkamah Agung (MA). Sedangkan administrative trial dapat digunakan secara langsung dan warganegara untuk memulihkan keadaan yang merugikan akibat tindakan kongkrit birokrasi.

Baik legislative review maupun anticipatory juducial review tidak hanya dilakukan di tingkat pusat, melainkan juga di tingkat daerah. Sedangkan administrative trial, seperti diketahui, dapat berlangsung sejak tingkat pertama (Pengadilan Tata Usaha Negara, PTUN), tingkat banding (di Pengadilan Tinggi TUN, PT-TUN), hingga tingkat kasasi di Mahkamah Agung.

Legislative review dilakukan oleh lembaga-lembaga perwakilan rakyat dengan 'mengawasi jalannya pemerintahan seharihari', yaitu melalui pelaksanaan fungsifungsi lembaga tersebut. Di tengah dorongan untuk meningkatkan otonomi daerah, peran ini makin penting. Tanpa peningkatan peran legislatif yang responsif terhadap aspirasi masyarakat, kiranya otonomi daerah tidak akan berjalan secara sungguh-sungguh. Sebab pengembangan otonomi daerah memerlukan partisipasi masyarakat luas, sedanǵkan peran serta masyarakat yang murni hanya muncul jika pandangan dan kepentingan mereka tersalurkan melalui lembaga perwakilan rakyat.

Anticipatory judicial review dikaitkan dengan fungsi non-yudisiil yang dimiliki MA. Kewenangan MA ini tak banyak memperoleh perhatian yang memadai dari kalangan 
Topik: Hukum dan Peningkatan Efisiensi Birokrasi, M. Fajrul Falaakh

ahli hukum. Padahal, seperti diketahui, MA memiliki kewenangan yang dikenal dalam kepustakaan hukum sebagai anticipatory judicial review dan/atau advisory function. Melalui kewenangan ini diharapkan agar MA tak hanya menjalankan tugas sebagai peradilan negara (juduciary), melainkan juga dapat ikut menumbuhkan keterbukaan (trannsparency) dan pertanggungjawaban (accountability) akan manajemen pemerintahan.

Hak uji antisipatif memang dirumuskan sangat longgar, bahkan lebih bersifat advisory dan tak mengikat. MA sekedar memberikan nasihat, pandangan atau pertimbangan hukum kepada lembaga-lembaga negara lainnya. Menurut UU No. 14/1970 Pasal 25, lembaga pengadilan memiliki anticipatory juducial review. Pasal ini berbunyi: "Semua Pengadilan dapat memberi keterangan, pertimbangan dan nasehatnasehat tentang soal-soal hukum kepada Lembaga Negara lainnya apabila diminta". Dalam Tap No. III/MPR/1978 anticipatory juducial review dapat dilakukan MA tanpa menunggu permintaan dari Lembaga $\mathrm{Ne}-$ gara lainnya. Pasal 11 ayat (2) berbunyi: "Mahkamah Agung dapat memberikan pertimbangan-pertimbangan dalam bidang hukum, baik diminta atau tidak, kepada lembaga-lembaga tinggi negara". Berbeda dari UU No. 14/1970 Pasal 25, secara harfiah anticipatory judicial review menurut Tap tersebut dilakukan oleh MA. Tapi tak perlu menjadi masalah hukum jika fungsi ini juga dilaksanakan di tingkat daerah (dan memang demikian), karena MA merupakan puncak lembaga peradilan dan merupakan satu kesatuan dengan pengadilan tingkat bawahnya (tak mengenal pemisahan horisontal).

Masalahnya adalah, dalam pandangan Tap No. III/MPR/1978 MA dapat bersikap pasif dan menolak untuk memberikan nasihat jika diminta, atau bersikap aktif tanpa diminta untuk memberi nasihat. Selain itu, hak uji antisipatif ini bersifat "lunak" (soft anticipatory judicial review), karena akibat hukum dari nasihat MA tak ditentukan secara tegas.

Sebetulnya hak uji antisipatif yang lunak ini masih berguna dalam penyelenggaraan negara Indonesia. la merupakan mekanisme pemberian pertimbangan dari ahli-ahli hukum (hakim), tak selalu dipublikasikan sehingga dapat menjaga citra Pemerintah, dan sekaligus melengkapi fungsi kepenasihatan DPA. Hak uji antisipatif juga membuka ruang gerak yang luas kepada MA untuk mewujudkan kemandiriannya, karena MA dapat memberikan pandangan hukumnya tanpa diminta.

Administrative trial (peradilan tatausaha negara, peratun) dilakukan, daiam hal terjadi benturan antara kepentingan pemerintah dengan kepentingan individual warganegara maupun kepentingan kolektif masyarakat (UU No. 5/1986: Penjelasan Umum angka 2). Melalui cara ini maka birokrasi diharapkan makin efisien, efektif dan bersih karena peradilan tata-usaha negara dapat digunakan sebagai mekanisme negatif-represif untuk memulihkan keadaan yang merugikan akibat mal-administrasi. Di samping itu, secara umum peratun merupakan mekanisme yang dapat 'membayangi' perilaku birokrasi agar efisien dalam arti benar-benar melayani kepentingan dan rasa keadilan masyarakat yang - dan menjaga watak demokratik negara (Fajrul Falaakh, 1993).

\section{Catatan Akhir}

Jika dipertimbangkan dengan seksama, uraian di muka lebih menunjukkan watak potensial hukum dalam mendukung usaha-usaha untuk menciptakan birokrasi yang efisien. Dalam kenyataan, banyak pihak - termasuk dunia usaha nasional 
dan investor asing - justru telah menelan pengalaman pahit ketika berurusan dengan lembaga-lembaga hukum di Indonesia. Ini menengarai, bahwa dukungan bidang hukum untuk meningkatkan efisiensi birokrasi masih bersifat potensial daripada aktual.

Fungsi legislative review, misalnya, menghadapi inertia lembaga perwakilan rakyat - baik karena para anggotanya khawatir akan risiko politik yang akan dipikulnya maupun karena kualitas para anggota lembaga tersebut memerlukan peningkatan yang serius. Ini masih ditambah dengan peran dominan eksekutif, yang tampaknya tidak mudah untuk dikurangi atau diimbangi oleh anggota lembaga perwakilan rakyat.

Dalam anticipatory judicial review, kita dihadapkan kepada lemahnya profesionalisme dan integritas hakim. Berbagai perilaku hakim yang belakangan menjadi bahan sorotan negatif di kalangan masyarakat, bahkan di tingkat MA, kiranya merupakan kendala yang harus ditanggulangi jika mekanisme ini diminta bantuannya untuk menopang efisiensi birokrasi. Bahkan, mungkin kesepakatan untuk mem-fungsikan anticipatory judicial review ini pun masih harus dicapai di antara pihak eksekutif dan yudikatif.

Mengenai peratun, selain kemandirian lembaga ini dalam menghadapi pihak eksekutif masih harus ditingkatkan terus-menerus, pemahaman dan keberanian masyarakat untuk mengoreksi birokrasi melalui jalur hukum ini juga masih harus dipupuk.

Dengan demikian disadari bahwa optimisme akan peran hukum dalam meningkatkan efisiensi birokrasi -yang terkesan di bagian awal tulisan ini, masih menyisakan agenda reformasi hukum. Sebagian dari agenda ini bersifat 'teknis' hukum, na- mun sebagian yang lain juga menyaingkut dimensi politik.

\section{Daftar Pustaka}

Beetham, D. 1987. Bureaucracy. (Minneapolis: University of Minnesota Press).

Cane, Peter. 1986. An Introduction to Administrative Law. (Oxford: Clarendon Press).

Cohen, Morris R. dan Felix S. Cohen.1951. Readings in Jurisprudence and Legal Philosphy. (Boston/Toronto: Little, Brown and Company).

Fajrul Falaakh, M. 1993. "Hukum dan Pembatasan Kekuasaan", Suara Merdeka 16/7-93.

Fajrul Falaakh, M. 1994. Survei Pendahuluan tentang Delegating Proviso dalam Undang-undang Indonesia 1966-1992. (Yogyakarta: PAU Studi Sosial UGM, Laporan Penelitian).

Fajur Falaakh, M. 1995. "Dinamika Juducial REview di Indonesia", UNISIA, No. 28/1995, hal. 81-90.

Heidenheimer, A.J. et.al. 1983. Comparative Public Policy: The Politics of Social Choice in Europe and America. (New York: St. Martin's Press).

Lev, Daniel'S. 1990, Hukum dan Politik di Indonesia. (Jakarta: LP3ES).

Republik Indonesia, Departemen Kehakiman. t.t. Peradilan Tata Usaha Negara. (Jakarta: Ditjen Hukum dan Perundang-undangan).

Wilson, James Q. 1992. "The Rise of the Bureaucratic State" dalam Frederick S. Lane (ed.), Current Issues in Publics Administration (New York: St. Martin's Press), hal. 55-120. 